

Original Research Article

https://doi.org/10.20546/ijcmas.2020..074

\title{
Nutritional and Physiological Requirement of Macrophomina phaseolina (Tassi) Goid. Causing Dry root rot of Chickpea
}

\author{
Mahendra Partap* and S. L. Godara \\ Department of Plant Pathology, College of Agriculture, S. K. Rajasthan Agricultural \\ University, Bikaner- 334006 (Raj.), India \\ *Corresponding author
}

Keywords

Dry root rot,

Macrophomina phaseolina, Media,

Temperature, $\mathrm{pH}$,

Chickpea

Article Info

Accepted:

15 December 2019

Available Online:

20 January 2020

\section{A B S T R A C T}

An experiment was conducted to study the nutritional requirement and effect of physiological parameters like temperature and $\mathrm{pH}$ on mycelial growth of different isolates of Macrophomina phaseolina causing dry root rot of chickpea. Five different solid media, five temperature range and five $\mathrm{pH}$ levels were tested for their effect on mycelial growth. All tested culture medium, temperatures and $\mathrm{pH}$ levels supported the mycelial growth of different $M$. phaseolina isolates. The potato dextrose agar was found better for mycelial growth of all the isolates followed by Czapek's dox agar. $M$. phaseolina isolates could grow over a wide range of temperature i.e. $20^{\circ} \mathrm{C}$ to $40^{\circ} \mathrm{C}$ but optimum growth was observed at $30^{\circ} \mathrm{C}$ temperaturefollowed by $35^{\circ} \mathrm{C}, 25^{\circ} \mathrm{C}, 20^{\circ} \mathrm{C}$ and minimum at $40^{\circ} \mathrm{C}$. The $\mathrm{pH}$ requirement of the $M$. phaseolina were showed that all the isolates could grow over a wide $\mathrm{pH}$ range of 5.0 to 9.0 but the optimum $\mathrm{pH}$ for its growth was found to be $\mathrm{pH}$ 7.0 followed by $\mathrm{pH}$ 6.0. The growth of the fungus was reduced both below and above the optimum $\mathrm{pH}$ value.

\section{Introduction}

Chickpea (Cicer arietinum L.) also known as Bengal gram is one of the most important winter season food legume crops grown in India. Chickpea is a member of the family Fabaceae and believed to be originated in South-Eastern Turkey. Chickpea is valued for its nutritive seeds; it is an essential source of cheap protein in many parts of the world for those who follow to a vegetarian diet. Chickpea is also rich in mineral content like phosphorus, calcium, magnesium, iron and zinc. Therefore, chickpea is an excellent heart healthy food that may be beneficial to coronary and cardiovascular disease. The importance of chickpea to include in crop rotation lies due to its ability to bind free 
atmospheric nitrogen in soil, which make it's a valuable crop for maintaining soil fertility (Ferguson et al. 2010).

Worldwide, the major chickpea producing countries are India, Australia, Myanmar, Ethiopia, Turkey, Russian Federation and Pakistan. India is the world leader in chickpea, share $67 \%$ production followed by Australia. In India, it is grown about an area of $10.56 \mathrm{mha}$ with production of $11.23 \mathrm{~m}$ tonnes and productivity of $1063 \mathrm{~kg} / \mathrm{ha}$. India is the largest chickpea producing country, highest production received from Madhya Pradesh (41\%) followed by Maharashtra (16\%) and Rajasthan (15\%) (Anon., 2017-18a). The total area and production of chickpea in Rajasthan are $1.57 \mathrm{~m}$ ha and $1.67 \mathrm{~m}$ tonnes, respectively having productivity of $1062 \mathrm{~kg} / \mathrm{ha}$ (Anon., 2017-18b).

Dry root rot (DRR) of chickpea caused by nectrotropic fungus Rhizoctonia bataticola (Taub.) Butler [Pycnidial stage: Macrophomina phaseolina (Tassi) Goid.] is emerging as a serious threat to the chickpea production worldwide (Pande and Sharma, 2010). Dry root rot in chickpea was first reported from India by Mitra (1931). The first report of root rot occurrence in chickpea along with wilt was made by Padwick (1948). Dry root rot (DRR) is a potentially emerging disease of chickpea in rainfed ecologies worldwide. The disease is gaining importance under the changing scenario of climate particularly in the semi-arid tropics of Ethiopia and in central and southern India (Pande et al., 2012). It causes enough yield losses that vary from $5 \%$ to $50 \%$ and may cause $100 \%$ losses in susceptible cultivars under favorable conditions. Higher temperature coupled with soil moisture deficit during crop growth stage especially at postharvesting is predisposing chickpea to dry root rot infection (Sharma and Pande, 2013). In order to culture the fungi artificially, it is necessary to supply all essential nutrients needed for their growth and development. Similarly, suitable temperature is also important for growth and metabolic processes of fungi. Therefore, the present investigation was carried out to study the nutritional requirement and effect of physiological parameters like temperature and $\mathrm{pH}$ on mycelial growth of different isolates of M.phaseolina in vitro.

\section{Materials and Methods}

The experiment was conducted at Department of Plant Pathology, College of Agriculture, SKRAU, Bikaner (Rajasthan). Dry root rot infested chickpea plant samples were collected from different chickpea growing areas of Rajasthan viz., Alwar, Bikaner, Churu, Hanumangarh, Jaipur, Jaisalmer, Jhunjhunu, Jodhpur, Sikar, Sri Ganganagarand Udaipur. Isolation of the pathogen was made from infested root portions of chickpea and purified by hypal tip method. The isolated fungus was identified on the basis of morphological characters. Confirmed pure cultures were observed under microscope and the stock cultures maintained on PDA slants and stored in refrigerator at $4^{0} \mathrm{C}$ for further studies. A total of ten isolates of $M$. phaseolina were isolated and subjected to nutritional requirement and physiological variability studies. These isolates were differentiated and codes were given as per Indian Railway abbreviations. The list of Macrophomina phaseolina isolates used in present study as under:

\section{Effect of different solid media}

The study of different solid media was undertaken to find out the superior media for the mycelial growth of $M$. phaseolina. Five different solid media, two semi-synthetic i.e. Potato dextrose agar (PDA) and Czapek's (Dox) medium and three synthetic media viz., 
Richard's agar, malt extract agar and Sabouraud dextrose agar were used and compared for this purpose. These agars based sterilized media were poured aseptically in to $90 \mathrm{~mm}$ diameter previously sterilized Petri plates@ 20 ml plate ${ }^{-1}$ which were sterilized in an electric oven at $180^{\circ} \mathrm{C}$ for 2 hours. The Petri plates were then inoculated aseptically by placing $5 \mathrm{~mm}$ disc taken out from the periphery of 7 days old culture and incubated for 7 days for media at $28 \pm 2{ }^{\circ} \mathrm{C}$. The growth of pathogen was recorded on different media.

\section{Effect of temperature}

It is a well-known phenomenon that the temperature yields considerable influence on the biochemical activity of pathogens. Twenty $\mathrm{ml}$ of PDA was poured in each of sterilized Petri plates. Each Petri plate was inoculated aseptically by placing a $5 \mathrm{~mm}$ disc in the centre from actively growing 7 days old culture on PDA in Petri dishes. The inoculated Petri dishes were incubated at20, 25, 30, 35 and $40 \pm 1^{0} \mathrm{C}$ temperature for 7 days.

\section{Effect of hydrogen ion concentration (pH)}

The study of different $\mathrm{pH}$ levels was undertaken with a view to ascertain the effect of different hydrogen ion concentration of the medium on growth of the fungus. The initial $\mathrm{pH}$ of the basal medium before autoclaving was adjusted from 5.0 to 9.0 with a difference of 01 using $\mathrm{N} / 10 \mathrm{NaOH}$ or $\mathrm{N} / 10 \mathrm{HCl}$. After autoclaving the $\mathrm{pH}$ was again tested. The inoculated Petri plates were incubated at $28 \pm 2^{0} \mathrm{C}$ for 7 days.

\section{Results and Discussion}

\section{Effect of culture media}

The mycelial growth of different $M$. phaseolina isolates on different culture media was presented in Table 2. The significant difference in mycelial growth was found between the isolates on different culture media. Maximum mycelial growth of isolates AWR (82.06 mm), BKN (90.0 mm), CUR (90.0 mm), DPA (86.67 mm), HMH (86.18 $\mathrm{mm})$, JSM (84.46 mm), JU (76.91 mm), JJN $(84.12 \mathrm{~mm})$, SGNR $(82.40 \mathrm{~mm})$ and UDZ $(72.10 \mathrm{~mm})$ was observed on potato dextrose agar (PDA) as compared to Czapek's (dox), malt extract agar, Richard's agar and Sabouraud dextrose agar.

On the basis of mean, the most appropriate culture media for mycelial growth among the isolates of $M$. phaseolina was found in order to potato dextrose agar $(83.49 \mathrm{~mm})$, Czapek's dox $(75.61 \mathrm{~mm})$, Richard's agar $(74.60 \mathrm{~mm})$, malt extract agar $(68.97 \mathrm{~mm})$ and Sabouraud dextrose agar $(65.64 \mathrm{~mm})$. All the tested culture medium supported the mycelial growth of different $M$. phaseolina isolates. The potato dextrose agar was found best for mycelial growth of all the isolates of M. phaseolina. Mycelial growth was also found better on Czapek's dox for AWR, BKN, JSM and SGNR; Richard's agar for CUR, HMH, JU, JJN and UDZ; malt extract agar for DPA isolates.

Among the different media (non synthetic and synthetic), potato dextrose agar supported the M. phaseolina with highest mycelial growth followed by Czapek's dox, Richard's agar, malt extract agar, while, minimum growth was recorded on Sabouraud dextrose agar. This finding coincides with EI-Wakil et al. (1985) reported Potato dextrose agar, Czapek's dox agar and Richard's medium supported the good growth of $M$. phaseolina. Several earlier workers tested and evaluated different culture media and they suggested that Potato dextrose agar was the best culture medium for mycelial growth and sclerotial formation of $M$. phaseolina (Ratnoo and Bhatnagar, 1991; Sharma et al., 2004; Salunkheet al., 2009; Khan et al., 2012 and Parmar et al., 2018). 
Table.1List of Macrophomina phaseolina isolates

\begin{tabular}{|c|l|l|}
\hline S. No. & \multicolumn{1}{|c|}{ Code } & \multicolumn{1}{|c|}{ Place of collection of isolates } \\
\hline 1. & Mp-AWR & Agricultural Research Station, Navgaon, Alwar \\
\hline 2. & Mp-BKN & Agricultural Research Station,Beechwal, Bikaner \\
\hline 3. & Mp-CUR & Farmer's field- Ratangarh, Churu \\
\hline 4. & Mp-DPA & Rajasthan Agricultural Research Institute,Durgapura, Jaipur \\
\hline $\mathbf{5 .}$ & Mp-HMH & Agricultural Research Sub-Station, Hanumangarh \\
\hline 6. & Mp-JJN & Farmer's field-Chidawa, Jhunjhunu \\
\hline 7. & Mp-JSM & Farmer's field- Suthar mandi, Jaisalmer \\
\hline 8. & Mp-JU & Agricultural Research Station, Mandor, Jodhpur \\
\hline 9. & Mp-SGNR & Agricultural Research Station, Sri Ganganagar \\
\hline $\mathbf{1 0 .}$ & Mp-UDZ & Rajasthan College of Agriculture, Udaipur \\
\hline & & \\
\hline
\end{tabular}

Table.2 Effect of different culture media on mycelial growth of Macrophomina phaseolina isolates

\begin{tabular}{|c|c|c|c|c|c|c|}
\hline \multirow[t]{2}{*}{ Isolates } & \multicolumn{5}{|c|}{ Mycelial growth $(\mathrm{mm})$ on different culture media } & \multirow[t]{2}{*}{ Mean } \\
\hline & $\begin{array}{c}\text { Czapek's } \\
\text { (Dox) }\end{array}$ & $\begin{array}{c}\text { Malt } \\
\text { Extract } \\
\text { Agar }\end{array}$ & $\begin{array}{c}\text { Potato } \\
\text { Dextrose } \\
\text { Agar }\end{array}$ & $\begin{array}{c}\text { Richard's } \\
\text { Agar }\end{array}$ & $\begin{array}{c}\text { Sabouraud } \\
\text { Dextrose Agar }\end{array}$ & \\
\hline AWR & 81.93 & 65.00 & 82.06 & 70.33 & 64.80 & 72.82 \\
\hline BKN & 84.50 & 82.00 & 90.00 & 82.33 & 71.33 & 82.03 \\
\hline CUR & 84.84 & 85.67 & 90.00 & 87.67 & 73.67 & 84.37 \\
\hline DPA & 78.18 & 81.33 & 86.67 & 54.67 & 58.00 & 71.77 \\
\hline HMH & 76.04 & 60.67 & 86.18 & 83.00 & 70.00 & 75.18 \\
\hline JSM & 83.54 & 77.67 & 84.46 & 80.00 & 65.33 & 78.20 \\
\hline JU & 71.04 & 65.00 & 76.91 & 79.33 & 62.50 & 70.96 \\
\hline JJN & 59.98 & 60.00 & 84.12 & 72.33 & 62.00 & 67.69 \\
\hline SGNR & 75.68 & 60.00 & 82.40 & 73.00 & 69.00 & 72.02 \\
\hline UDZ & 60.33 & 52.33 & 72.10 & 63.33 & 59.80 & 61.58 \\
\hline Mean & 75.61 & 68.97 & 83.49 & 74.60 & 65.64 & 73.66 \\
\hline & & \multicolumn{2}{|c|}{ S.Em $( \pm)$} & \multicolumn{2}{|c|}{$\mathrm{CD}(\mathrm{P}=0.05)$} & $\begin{array}{l}\text { CV } \\
(\%)\end{array}$ \\
\hline \multicolumn{2}{|c|}{ Isolates } & \multicolumn{2}{|c|}{0.59} & \multicolumn{2}{|c|}{1.60} & 3.09 \\
\hline \multicolumn{2}{|c|}{ Media } & \multicolumn{2}{|c|}{0.42} & \multicolumn{2}{|c|}{1.13} & \\
\hline \multicolumn{2}{|c|}{ Isolates X Media } & \multicolumn{2}{|c|}{1.31} & \multicolumn{2}{|c|}{3.58} & \\
\hline
\end{tabular}


Table.3 Effect of different temperature on mycelial growth of Macrophomina phaseolina isolates

\begin{tabular}{|c|c|c|c|c|c|c|}
\hline \multirow[t]{2}{*}{ Isolates } & \multicolumn{5}{|c|}{ Mycelial growth (mm)on different temperature } & \multirow[t]{2}{*}{ Mean } \\
\hline & $20^{\circ} \mathrm{C}$ & $25^{\circ} \mathrm{C}$ & $30^{\circ} \mathrm{C}$ & $35^{\circ} \mathrm{C}$ & $40^{\circ} \mathrm{C}$ & \\
\hline AWR & 52.67 & 67.83 & 76.33 & 70.33 & 17.67 & 56.97 \\
\hline BKN & 69.33 & 84.67 & 90.00 & 88.00 & 31.00 & 72.60 \\
\hline CUR & 55.00 & 69.00 & 78.00 & 72.67 & 18.33 & 58.60 \\
\hline DPA & 67.67 & 80.67 & 84.00 & 82.33 & 23.67 & 67.67 \\
\hline HMH & 66.67 & 77.33 & 80.17 & 72.33 & 16.33 & 62.57 \\
\hline JSM & 52.00 & 65.00 & 79.07 & 80.33 & 19.33 & 59.15 \\
\hline JU & 57.67 & 73.33 & 70.67 & 69.67 & 20.00 & 58.27 \\
\hline JJN & 48.33 & 60.33 & 74.67 & 67.33 & 13.00 & 52.73 \\
\hline SGNR & 42.00 & 57.00 & 73.50 & 64.67 & 10.67 & 49.57 \\
\hline UDZ & 48.33 & 60.33 & 58.67 & 56.67 & 9.00 & 46.60 \\
\hline \multirow[t]{2}{*}{ Mean } & 55.97 & 69.55 & 76.51 & 72.43 & 17.90 & 58.47 \\
\hline & & \multicolumn{2}{|c|}{ S.Em $( \pm)$} & \multicolumn{2}{|c|}{$\mathrm{CD}(\mathrm{P}=0.05)$} & $\mathrm{CV}(\%)$ \\
\hline \multicolumn{2}{|c|}{ Isolates } & \multicolumn{2}{|c|}{0.50} & \multicolumn{2}{|c|}{1.37} & 3.32 \\
\hline \multicolumn{2}{|c|}{ Temperature } & \multicolumn{2}{|c|}{0.35} & \multicolumn{2}{|c|}{0.97} & \\
\hline \multicolumn{2}{|c|}{$\begin{array}{c}\text { Isolates X } \\
\text { Temperatue }\end{array}$} & \multicolumn{2}{|c|}{1.12} & \multicolumn{2}{|c|}{3.06} & \\
\hline
\end{tabular}

Table.4 Effect of different pH levels on mycelial growth of Macrophomina phaseolina isolates

\begin{tabular}{|c|c|c|c|c|c|c|}
\hline \multirow[t]{2}{*}{ Isolates } & \multicolumn{5}{|c|}{ Mycelial growth (mm) on different pH levels } & \multirow[t]{2}{*}{ Mean } \\
\hline & 5.0 & 6.0 & 7.0 & 8.0 & 9.0 & \\
\hline AWR & 64.83 & 63.70 & 56.33 & 59.33 & 49.58 & 58.76 \\
\hline BKN & 77.70 & 82.20 & 83.10 & 72.00 & 64.00 & 75.80 \\
\hline CUR & 70.63 & 75.25 & 80.00 & 64.33 & 60.07 & 70.06 \\
\hline DPA & 82.90 & 90.00 & 90.00 & 76.00 & 64.32 & 80.64 \\
\hline HMH & 73.37 & 77.70 & 82.20 & 67.00 & 62.67 & 72.59 \\
\hline JSM & 76.57 & 79.10 & 82.67 & 71.00 & 63.47 & 74.56 \\
\hline $\mathbf{J U}$ & 64.47 & 73.50 & 70.00 & 59.00 & 61.77 & 65.75 \\
\hline JJN & 70.30 & 63.00 & 76.33 & 64.33 & 55.82 & 65.96 \\
\hline SGNR & 70.93 & 75.60 & 77.33 & 64.67 & 63.75 & 70.46 \\
\hline UDZ & 56.50 & 52.50 & 60.67 & 51.33 & 45.62 & 53.32 \\
\hline \multirow[t]{2}{*}{ Mean } & 70.82 & 73.26 & 75.86 & 64.90 & 59.11 & 68.79 \\
\hline & & \multicolumn{2}{|c|}{ S.Em $( \pm)$} & \multicolumn{2}{|c|}{$\mathrm{CD}(\mathrm{P}=0.05)$} & $\mathrm{CV}(\%)$ \\
\hline \multicolumn{2}{|c|}{ Isolates } & \multicolumn{2}{|c|}{0.70} & \multicolumn{2}{|c|}{1.90} & 3.92 \\
\hline \multicolumn{2}{|c|}{ pH } & \multicolumn{2}{|c|}{0.49} & \multicolumn{2}{|c|}{1.34} & \\
\hline \multicolumn{2}{|c|}{ Isolates X pH } & \multicolumn{2}{|c|}{1.56} & \multicolumn{2}{|c|}{4.25} & \\
\hline
\end{tabular}




\section{Effect of temperature}

The effect of temperature on mycelial growth of various isolates of $M$. phaseolina was studied by incubating Petri dishes at different temperatures ranging from 20 to $40^{\circ} \mathrm{C}$. Maximum mycelial growth of isolate $\mathrm{BKN}$ (90.0 mm), DPA (84.00 mm), HMH (80.17 $\mathrm{mm})$, CUR (78.0 mm), AWR (76.33mm), JJN $(74.67 \mathrm{~mm})$ and SGNR $(73.50 \mathrm{~mm})$ were observed on $30^{\circ} \mathrm{C}$. Isolate $\mathrm{JU}(73.33 \mathrm{~mm})$ and UDZ $(60.33 \mathrm{~mm})$ were showed maximum mycelial growth on $25^{\circ} \mathrm{C}$, while isolate JSM $(80.33 \mathrm{~mm})$ was on $35^{\circ} \mathrm{C}$ temperature.

Isolate $\mathrm{HMH}, \mathrm{JU}$ and UDZ showed comparatively increased mycelial growth on $25^{\circ} \mathrm{C}$ as compared to $35^{\circ} \mathrm{C}$. Minimum mycelial growth was observed in all the isolates on $40^{\circ} \mathrm{C}$ temperature (Table 3 ).

The significant effect of temperature range was found on mycelial growth of different isolates of $M$. phaseolina. The overall mycelial growth among the isolates of $M$. phaseolina were recorded maximum at $30^{\circ} \mathrm{C}$ than $35^{\circ} \mathrm{C}, 25^{\circ} \mathrm{C}, 20^{\circ} \mathrm{C}$ and minimum at $40^{\circ} \mathrm{C}$.

The mycelial growth of $M$. phaseolina isolates were increased when increase in temperature up to $30^{\circ} \mathrm{C}$ but there after increase in temperature decreased the growth. A significant difference was found among the isolates, different temperatures and their interactions. This result coincides with the finding of Dhingra and Sinclair (1973), Patel and Patel (1990), Ratnoo and Bhatnagar (1991), Khan et al. (2012), Parmar et al. (2018) and Thombre and Kohire (2018), they reported that the optimum temperature range of 25 to $35^{\circ} \mathrm{C}$ found optimum for growth and sclerotial formation by $M$. phaseolina whereas, $<15^{\circ} \mathrm{C}$ and $>40^{\circ} \mathrm{C}$ temperature did not favour the mycelial growth as well as sclerotia production.

\section{Effect of pH}

Hydrogen ion concentration also affected the growth of $M$. phaseolina tested over a wide range of $\mathrm{pH} 5.0$ to 9.0. The $\mathrm{pH} 7.0$ was found optimum for maximum growth of isolate BKN, CUR, DPA, HMH, JSM, JJN, SGNR and UDZ, while AWR and JU isolate was at pH 6.0.

The mean optimum $\mathrm{pH}$ for all the isolates were 7.0 followed by $6.0,5.0$ and 8.0 and least was $\mathrm{pH}$ 9.0. The data revealed that all the isolates showed good growth over a wide range of $\mathrm{pH} 5.0$ to 9.0. There was a significant difference between among the isolates, different $\mathrm{pH}$ levels and their interactions (Table 4).

In present investigations the maximum growth was observed at 6.0 to $7.0 \mathrm{pH}$ as concluded by Singh and Chauhan (1982) reported the growth of $M$. phaseolina between $\mathrm{pH}$ 2.0-9.0, where $\mathrm{pH}$ 5.0-6.0 were found optimum. Jha and Dubey (2000) also recorded that the pathogen $M$. phaseolina causing charcoal rot of okra grew on wide range of $\mathrm{pH}$ i.e. between 4.0 and 8.0, where $\mathrm{pH} 6.0$ to 7.0 being optimum. Khan et al. (2012) investigations correlate with the present findings, it could grow over a wide $\mathrm{pH}$ range of 3.0 to 9.0 but the optimum $\mathrm{pH}$ for its growth was found to be 5.5. Thombre and Kohire (2018) reported that a wide range of $\mathrm{pH}$ supported the growth of $M$. phaseolina. The best $\mathrm{pH}$ level for mycelial growth was found to be 7.0.

\section{Acknowledgement}

The authors are grateful to the Department of Plant Pathology, College of Agriculture, Swami Keshwanand Rajasthan Agricultural University, Bikaner for providing facilities to conduct this research. 


\section{References}

Anonymous. 2017-18a. Directorate of Economics and Statistics, Department of Agriculture and Cooperation, Ministry of Agriculture \& Farmers Welfare, Govt. of India, New Delhi. 2018. www.agricoop.nic.in.

Anonymous. 2017-18b. DOA, Department of Agriculture, Govt. of Rajasthan, Jaipur, www.krishi.rajasthan.gov.in

Dhingra, C. D. and Sinclair, J. B. 1973. Variation among the isolates of Macrophomina phaseolina (Rhizoctonia bataticola) from different regions. Phytopathology. 76: 200-204.

EI-Wakil, S. A., Haggag, M. H., Machali, H. H. and Saasd, E. A. 1985. Radiation transfer in dispersive media. J. Phys. D: Appl. Phys., 18: 1469.

Ferguson, B. J., Indrasumunar, A., Hayashi, S., Lin, M. H., Lin, Y. H., Reid, D.E. and Gresshoff, P. M. 2010. Molecular analysis of legume nodule development and autoregulation. J. Integr. Plant Biol., 52: 61-76.

Jha, A. K. and Dubey, S. C. 2000. Occurrence of collar rot of okra (Abelmoschus esculantus) in the plateau region of Bihar. J. Res. Birsa Agril. Uni., 12(1): 67-72.

Khan, R. A., Bhat, T. A. and Kumar Krishan. 2012. Management of Chickpea (Cicerarietinum L.) Dry root Rot Caused by Rhizoctonia bataticola (Taub.) Butler. Intrn. J. Res. Pharma. and Biom. Sci., 3(4): 1539-1548.

Mitra, M. 1931. Report of the imperial mycologist. Sci. Rep. of the Agric. Res. Inst., 1929- 1930: 58-71.

Padwick, G. W. (1948). Plant protection and food crops of India, plant pest and disease at rice, wheat, sorghum and gram. Imperial J. Exp. Agri., 16: 55-64.

Pande, S. and Sharma, M. 2010. Climate change: Potential impact on chickpea and pigeonpea diseases in rainfed semiarid tropics (SAT). Presented in 5th International Food Legumes Research Conference (IFLRCV) and European conference on Grain Legumes (AEP VII), April 26-30, Antalya, Turkey.

Pande, S., Sharma, M., Nagavardhini, A. and Rameshwar, T. 2012. High Throughput Phenotyping of Chickpea Diseases: Stepwise identification of host plant resistance. Information Bulletin No. 92 Patancheru 502 324, Andhra Pradesh, India: International Crops Research Institute for the Semi Arid Tropics. pp. 56.

Parmar, H., Kapadiya, H. J., Bhaliya, C. M. and Patel, R. C. 2018. Effect of Media and Temperature on the Growth and Sclerotial Formation of Macrophomina phaseolina (Tassi) Goid causing Root Rot of Castor. Int. J. Curr. Microbiol. App. Sci., 7(02): 671-675.

Patel, K. K. and Patel, A. J.1990. Meteorological correlation of charcoal rot of sesamum. J. Mycol. Pl. Pathol., 20(1): 64-65.

Ratnoo, R. S. and Bhatnagar, M. K. 1991. Effect of temperature and $\mathrm{pH}$ on growth and sclerotia formation of $M$. phaseolina. J. Mycol. Pl. Pathol., 21(3): 279-280.

SalunkheVanita, Sarika Armarkar and Ingle, R. W. 2009. Effect of nutritional and physiological factors on growth and sclerotial formation of $R$. bataticola (Taub.) Butler isolates. J. Pl. Dis. Sci.,4(1): 44-48.

Sharma, M, and Pande, S. 2013. Unravelling Effects of Temperature and Soil Moisture Stress Response on Development of Dry Root Rot [Rhizoctonia bataticola (Taub.)] Butler in Chickpea. American J. Pl. Sci.,4: 584-589.

Sharma, V. K., Gaur, R. B. and Bisnoi, H. R. 2004. Cultural, morphological and 
physiological variability in Thombre, B. B. and Kohire, O. D. 2018. Macrophomina phaseolina. J. Mycol. Nutritional and physiological studies of Pl. Pathol., 34: 532- 534.

Macrophomina phaseolina (Tassi) Goid

Singh, R. S. and Chauhan, J. S. 1982. Physiopathological studies of Macrophomina phaseolina causing charcoal rot in muskmelon. Indian J. Mycol. Pl. causing mungbean blight. International Journal of Chemical Studies. 6(2): 3058-3062.

Pathol., 12: 81-82.

\section{How to cite this article:}

Mahendra Partap and Godara, S. L. 2020. Nutritional and Physiological Requirement of Macrophomina phaseolina (Tassi) Goid. Causing Dry root rot of Chickpea. Int.J.Curr.Microbiol.App.Sci. 9(01): 690-697. doi: https://doi.org/10.20546/ijcmas.2020.901.074 